\title{
Loss of Identity in Ayad Akhtar's American Dervish
}

\author{
Ragab Selim Ali \\ Dept. of Foreign Languages, Faculty of Education, Mansoura University, Cairo, Egypt
}

\section{Email address:}

drragab_111@hotmail.com

\section{To cite this article:}

Ragab Selim Ali. Loss of Identity in Ayad Akhtar's American Dervish. International Journal of Literature and Arts. Vol. 3, No. 5, 2015, pp. 80-87. doi: 10.11648/j.jila.20150305.13

\begin{abstract}
This paper focuses on the concept of the loss of identity in Ayad Akhtar's debut novel American Dervish. The novel explicates the inability of the Muslim protagonist, Hayat Shah, to assimilate himself into community as far as he still holds on his remnant tenets he has inherited from his homeland Pakistan. This theme is overtly applied to both Hayat's character as well as his father's. Hayat represents the younger generation while his father represents the older one. They both follow the same path in that Hayat finds his identity in befriending the Jewish girl Rachel as well as in discarding the Islamic tenets, taught by his mentor Mina; in the meantime, his father finds his identity in accompanying his lifelong workmate-Nathan Wolfsohn, a Jewish professor. With regard to this point, Ayad Akhtar's message to the readers perhaps lies in the way the immigrants to the west in general and to America in particular encounter the so many teething troubles in their lives until they find a path to assimilate themselves into their new community.
\end{abstract}

Keywords: Loss of Identity, Assimilation, Dervish, ISLAM, Jewish, Community, Tenets

\section{Author and the Study}

\subsection{Author}

Ayad Akhtar (b. 1970) is a Pakistani-American dramatist, novelist, screenwriter, and actor. His play Disgraced awarded him the Pulitzer Prize for Drama in 2013. American Dervish is Akhtar's debut novel, which has been "published in more than 20 languages worldwide and a 2012 Best Book of the Year at Kirkus Reviews, Toronto's Globe and Mail, ShelfAwareness, and O (Oprah) Magazine" (AyadAkhtar, Bio). Akhtar is also recognized as a great author according to what Wendy Smith observes in The Washington Post "Akhtar's poignant and wise debut announces the arrival of a generous new voice in American fiction." Furthermore, Ayad Akhtar, who is a first-generation Pakistani-American author "has written an immensely entertaining coming-of-age story set during the early 1980s among the Pakistanis in the author's hometown, Milwaukee (Adam Langer)."

\subsection{Significance of the Study}

The present paper is perhaps the first study to focus on American Dervish (2012) by Ayad Akhtar and the theme of the loss of the Muslim Pakistani-American identity regarding those people who lived in America during the 80s of the twentieth century. American Dervish might be regarded as a mirror of the community of the immigrants where the author still lives. This research also deals with the loss of identity since "Identity is not fixed and singular. It is fluid, multiple, relational and in process (Tsang Sze Pui, Jappe 5)." Everyone is apt to the 'fluidity' and 'multiplicity' of his/her own identity. The researcher manipulates the analytical study method in order to show how Ayad Akhtar makes use of characterization, plot, and the interrelations between characters to convey the theme of the loss of identity to the readers. This study also focuses on the intimacy between the Muslim immigrants and their religion. Lisa Irene Moody brings into light the significance of religion in societies when she argues that "the connection between religion, ethics, and the surrounding social world is one that seems unavoidable ... (Moody 25)." Again, Shih-Yi Huang points out that "religion can play an important role in defining a person's identity (Shih-Yi Huang 31)." In his paper, Noorbakhsh Hooti stresses the importance of identity notion when he says that "The loss of identity and the quest for it has been the pervasive theme in contemporary American literature." Crosby, again in her Ph.D. dissertation, observes that "People experience identity through communication, meaning that identity is often framed in terms of enactments or how they express their identity to those around them (Crosby 16)." Again, there are many elements that have their ineffable impact on the identity of anyone such as religion, 
culture, country, and community, to mention the most important. In her Ph.D. dissertation, Heike Berner notices that "Culture, history, and ethnicity are three central and closely intertwined aspects which influence identity formation (Berner 11)."

This novel centers on Hayat Shah, a Pakistani-American preteen boy and the protagonist of the novel who lives with his father and mother in "Milwaukee's rural westerly suburbs a stone's throw from dairy country, ... (American Dervish 25)." Hayat Shah is the most representative character of the second generation of the Pakistani immigrants to the States whereas his father Naveed Shah best displays the loss of identity of the first generation in the novel. Marcie Sillman points out that "Akhtar also explored the subject of identity in his first published novel, 'Dervish."' Since Hayat Shah and his father are two of the most important characters in the novel, this paper will shed light on only these two characters in respect of the loss of identity.

\subsection{Beginning of American Dervish}

The prologue of American Dervish opens with Hayat Shah who spends his most joyful moments with the Jewish girl Rachel. At the outset of the novel and in class, Hayat befriends his classmate, Rachel whose beauty and courtesy infatuates him. With Rachel, Hayat is ready to attend Professor Edelstein's lecture, which is a "Survey of Islamic History in fifteen minutes." The professor refers to a survey made by one of his German colleagues regarding the Quran. The conclusion to which the German scholar has come can be summarized in the following quotation: "In short, Edelstein claimed, his German colleague was about to show the world that the bedrock Muslim belief in the Quran as the direct, unchanged, eternal word of God was a fiction (American Dervish 62)." In class, there are only three Muslim students: Hayat, Ahmed and Sahar. The last two angrily leave the class while Hayat stays in class with his Jewish girlfriend - Rachel. Hayat, unaffected by what is said about the Quran, says that he is "a true and tried Mutazalite," which is not true. Later, he confides this to Rachel, his beloved. The author divides his novel into a prologue, four books, each book is composed of four chapters except Book Two, which comprises five chapters. After the four books comes the epilogue.

\section{Mina and Her Aborted Attempt to Tutor Hayat Shah}

\subsection{Mina Ali from Pakistan to America}

At the very start of Book One, Hayat's mother Muneer Shah talks to him about her best friend Mina Ali who is coming to the States from Pakistan a year after her unbearable marriage to Hamed Suhail. Before she comes, Hamed sends her his attorney to tell her that "he [Hamed] divorces you, he divorces you, and he divorces you (American Dervish 5)." In this respect, the attorney adds,
"You have just given birth to Hamed Suhail's son. He has chosen the name Imran for the boy. Imran will stay with you until the age of seven, at which point Mr. Hamed Suhail has the right to full, undisputed custody (American Dervish 5)."

To flee from such a horrid milieu, Mina accepts the invitation from the Shah's family to live with the Shahs in Milwaukee, Wisconsin. Hayat very well observes that Mina's son Imran is magnetized by his father Naveed and he himself to Mina. Hayat points out: "I loved her voice. And I loved being so close to her. My days now revolved around the anticipation of that nighttime hour... listening-my eyes closed-to her breathy voice as she told bedtime tales (American Dervish 32)."

By the time Mina Ali comes to the States, Hayat, who has been enchanted by his mentor Mina, begins to learn some of the Islamic tenets: how to be a dervish and how to memorize the Quran. It is only Mina who cares about teaching Hayat the Islamic tenets: his parents, on the other hand, do care nothing about this point. "There's Hayat's father, a secular humanist who doesn't want to be bound by the limits of scripture (Writing About The Midwestern Muslim Experience)." Further, his mother turns a deaf ear to these religious creeds. Hayat memorizes the Quran in English and he learns third of the Book by heart. To him, the dearest dream to fulfill in life is to become a hafiz; meanwhile, Mina recounts the story of the dervishes to Hayat so that he might someday become one of them. She would like to see him behave and act like the dervish, mentioned in Mina's tale, sitting at the side of the road and looking at two people who are eating oranges. When the dervish looks at them, they spurn him and wonder why he is doing so. They, then, toss him with the orange peels. Instead of getting angry, the dervish thanks them (American Dervish 87). In this respect, Mina adds: "In fact, he realized he was the same as that ground, the same as those peels, as those men, as everything else. He was the same as everything created by Allah's hand (American Dervish 88)."

\subsection{Mina Tutors Hayat to Be a Hafiz}

Because Hayat is being taught to be a hafiz at the hands of Mina, he, at the end of Book Two, begs God not to let his father be scourged in the flames of Hellfire because of his sins. Hayat observes, "I saw Father waving at me through the endless flames. I begged God to forgive him, to turn him away from his sins. I heard Father's cries of pain as the fires burned him (American Dervish 136)." To save his father from the tortures of Hellfire is the reason why Hayat is eager to be a hafiz. "That's what Mina had said. Every hafiz earned not only his own place in Paradise, but his parents' as well. No matter how many drinks, no matter how many mistresses, Father would be saved (American Dervish 137)."

Hayat's infatuation with Mina is shown not only spiritually, but physically as well. He begins to physically love her, especially after having seen her naked body in the bathroom. Hayat points out, "I had never seen anything so perfect as her naked body, its swelling at the chest and hips... My heart stirred. Something inside me was already burning (American 
Dervish 56)." Out of his physical love for Mina and his enthusiasm for learning the Islamic teachings, Hayat cannot accept her being married to Nathan, a Jewish man. Accordingly, he sends a telegram to her parents in Pakistan, telling them that their divorced daughter will marry a Jewish man. Mina's parents arrive and prevent such a marriage. For that reason, Mina is married to a Muslim man, Sunil, with whom her life becomes a piece of hell perhaps more austere than that life she has spent with Hamed Suhail to the extent that she dies of uterine cancer. When she passes away, she does so without complaining in an attempt to display her intimacy and close relationship with the life of a dervish and what such a life behooves her to do.

\subsection{Hayat's Beginnings to Abjure Religion}

Since Hayat's parents, Naveed and Muneer, are irreligious, Mina takes the responsibility to fill this gap in Hayat's life. Hayat never hears any religious stories from his parents; all he hears from his mother are her stories about his father's white mistresses (American Dervish 33). Out of Muneer's sufferings at the hands of her husband, she starts to instill into her son the opinion that he should eschew the Muslim behavior of treating women and adopt the Jewish one. Many a time, Muneer tells her son that she would like to see him behave like a Jew, not like a Muslim. In an attempt to remind her son of her message to him, she says: "That's why I'm bringing you up differently, so that you learn how to respect a woman. That's the truth, kurban: I'm bringing you up like a little Jew (American Dervish 101)." Mother never spares any time or effort to show Hayat how the Jews are utterly different from the Muslims in treating women; the Jews treat them reverentially, but the Muslims disrespectfully. Muneer adds: "They understand how to respect women, behta. They understand how to let a woman be a woman, to let her take care of them. They understand how to give a woman attention (American Dervish 101)." It overtly seems that Hayat inherits his love for the Jews from his mother while she inherits it from her father. Muneer's father "instilled in his children a belief that Jews were the special people, blessed by God above others. . . (American Dervish101)." Hayat's fathers and forefathers derive their notions about the Jews from their experiences with them. Hayat points out that his grandfather's respect for the Jews "stemmed from his experience living in their midst as a student in England in the years after the Second World War (American Dervish 101)." To Hayat's grandfather, the Jews greatly respect learning while Muslims do not: he believes that the Jews' learning is a real one, "not the rote memorization and mindless regurgitation of tradition he saw as common to Muslims (American Dervish 101)." What Hayat's grandfather says about Muslims can be plainly applied to what Hayat says or does in the novel.

\subsection{Hayat's Repugnance of His Past Life}

To express his loathsome upbringing as a child at the hands of Mina who wishes to see him as a hafiz or a dervish,
Hayat says, "My soul was outgrowing the child-sized raiment with which my Islamic childhood had outfitted me (American Dervish 316)." In the epilogue, Hayat firmly states: "It was in Rachel's arms - and it was with her love - that I finally discovered myself not only as a man, but as an American (American Dervish 329)." Since Hayat finds his identity nowhere but in the company of the Jewish girl, Islam no longer means anything to him. "My heart yearned to pray. I put my hands out before me in the Muslim style and tried to conjure the heartfelt fire I knew so well from back when Mina lived with us. But my words rang hollow. Like sounds spoken to the deaf, or worse, to no one at all (American Dervish 317)."

Just before the epilogue, Hayat, speaking to Mina, uncovers his renouncing of Islam and its tenets, not abruptly, but gradually. "I wanted to tell her [Mina] that I had been giving up on Islam little by little for years, and that now there was barely anything left (American Dervish 325)." To make matters worse, before leaving Islam behind his back, Hayat's two acquaintances Farhaz and Hamza teach him a handful of dirty words in English.

Again, in the last chapter (Chapter 17), Hayat plainly points out that he has barely touched the Quran for the last ten years. Moreover, he has just abnegated the kind of respect he once had towards the Quran.

"Inside the library, the return bin was filled with books. I didn't give the moment much thought. I didn't kiss the cover as I usually did. I just put the Quran down on top of the other books and watched it slide to one side, tumbling out of view. It was the last Quran I would touch for almost ten years (American Dervish 341)."

\subsection{Neither a Dervish nor a Hafiz}

By the end of the novel, the reader realizes the fact that Hayat cannot be the American dervish for many reasons. First, he now discards all the Islamic teachings and tenets. He also points out that his identity in America hinges solely on his intimacy with the Jewish people and community, especially with Rachel. In doing so, Hayat has to renounce his fellow people, the Muslims in general, and the Pakistanis, in particular. As shown at the end of the novel, when Hayat wants to know more information about Mina's two children after her death, it is Professor Nathan Wolfsohn, the Jewish professor, who informs him about their lives. It is quite obvious that Hayat gets his information about Pakistani people from Professor Wolfsohn who still profoundly respects the departed Mina.

Secondly, the reader is fully aware of the fact that Hayat cannot be the American dervish since he, in his dream, does not stay with the Prophet till they perform the prayer. "Mina had said it was a great blessing to see the Prophet in a dream, but there didn't seem to be any blessing in mine. Instead of staying and praying with him, I'd left (American Dervish 213)."

Third, Hayat cannot put up with any severe trial in his life. He could not digest the idea that Professor Nathan might marry aunt Mina even though he is quite ready to be 
converted to Islam for her own sake. Nearly at the end of the novel when both Hayat and Professor Nathan meet, the latter says: "I never got over your aunt. She was, and always will be, the love of my life (American Dervish 333)." Again, Hayat could not attain or show enough patience with his father's austere vicissitudes that undesirably upset his relations with his family. Instead of giving advice to his father not to drink or pursue the white American mistresses, he collaborates with his mother to unearth his father's points of weaknesses. While Hayat is eavesdropping on his father and the nurse's flirtatious acts, he becomes fully aware of his father's debauched deeds. Hayat explains how he catches his father at that moment: "He was listening as she talked, every part of him leaned in toward her. He sipped at a drink, nodding. He looked happy. They both did. And then he kissed her (American Dervish 288)." The author assiduously attempts to show to what extent the father-son relation is torn asunder. The son is keeping an eye on the father while the father's posture may fall apart once the father glimpses his son, watching him. "As if sensing something, Father stopped. His gaze turned to the window. Our eyes met. He froze. Then the woman turned to look. I recognized her now. It was the nurse from the hospital room. Julie (American Dervish 288)."

Mina, on the other hand, is the best character in the novel who has forborne all the woes and throes she has come across. She never complains of any wrongdoings committed by any character against her. Further, she, in an attempt to teach Hayat how to be a dervish, uncovers one of her best traits. Her being a new dervish or the American dervish is quite apparent in her following sermon, delivered to Hayat to teach him what it means to be a dervish. It is a mental state when life and death, happiness and sadness, and castles and prisons are all the same in her eyes. This is because she thinks of nothing but the path to God. Mina says:

Faith has never been about an afterlife for me, Hayat. It's about finding God now. In the everyday. Here. With you. Whether I'm living in a prison or in a castle. Sick or healthy. It's all the same. That's what the Sufis teach. What comes our way, whatever it is, that is the vehicle. Every single life, no matter how big or small, how happy or how sad, it can be a path to Him (American Dervish 326)."

Mina adds that being a dervish perhaps means losing identity, dignity and even personality. Such an image of a true dervish is the other side of assimilation into any community. She openly declares that she could be a speck of dust, or a grain of sand, or nothing at all so that she will not hurt or be hurt by anybody on earth. In doing so, she best practices the meaning of assimilation to the extent that she does not care about the outer forms of her religion; therefore, "She didn't wear a head scarf;" nor did she fast in Ramadan (American Dervish 50). To show the meaning of a true dervish or Sufi, Mina observes:

'To be a Sufi,' she continued, 'means to give up the world and everything in it. To be a Sufi means to depend on nothing, to want nothing, to be nothing. A Sufi is a day that needs no sun, a night that needs no moon, no stars. A Sufi is like the dust on the ground, not the stones that hurt people's feet when they walk, but the dust that no one knows is even there (American Dervish 258).

When one examines the aforementioned characteristics of a dervish or a Sufi, it seems quite apparent that Mina is the true one. She marries Hamid Suhail who divorces her three times and threatens her to take his son back to his custody. It is also Mina who accepts the invitation to come to Milwaukee, accompanied by her son Imran, to live as two guests with Hayat's father and mother. Mina teaches Hayat Quranic lessons for nothing, quits teaching him when his father asks her to do so, cooks food for them like a maid, shows her utter readiness to marry the Jewish man, marries the sadistic man Sunil Chatha whose white American wife divorces him, and lastly dies at the hands of Sunil after a long period of wretchedness. To comply with what society imposes upon her, Mina changes her physical form in a way to assimilate herself into community. "Her fashionable hairstyle made her a modern woman, an American woman, an astonishing prospect to folks like us who never would have thought we could look like that (American Dervish 53)." Again, part of her assimilation into society is displayed in her unwavering willingness to marry the Jewish man, Professor Wolfsohn.

It is also quite obvious that Mina, not Hayat, is the dervish in the novel since it is she, not he, who can attain the true traits of a real dervish. It is worth noting that Hayat is the one who struggles with the American mores in search of his identity, a search which ends in abjuring his Islamic tenets so that he can find his resort in assimilation.

On the other hand, Hayat cannot be a hafiz for many reasons. First, he has been tutored by Mina who teaches him the Quran in English, not in Arabic. Mina, to mention her point of view, asserts that all deeds are weighed on intentions, not appearances or forms. Out of this standpoint, Mina teaches Hayat how to memorize the Quranic verses in English. Souhef the Imam refutes this viewpoint, telling Hayat "You have to learn the holy book in our holy language for that. But don't be discouraged. You have all the time in the world (American Dervish 301)." Second, Hayat's relation with Mina is not only spiritual, but physical as well. Such a relation is sturdily cemented immediately after Hayat eyes her naked body while she is having a shower. The image of Mina's naked body seems to be persistent and prevalent in his life.

The image I thought I'd taught myself to forget would return, unbidden - her breasts; ... - and hours of confusion and unrest would ensue. I made fresh attempts to suppress the mental picture. To no avail. The more I resisted, the more persistent it proved (American Dervish 161).

Later, he leans down in order to give Mina a kiss. The affectionate relation between the two seems to be mutual and both admit it. After kissing her, the following short dialogue ensues:

"That's so sweet, behta."

"I love you, Auntie."

"I love you, too, Hayat (American Dervish 192)."

Hayat's mind is not only obsessed with Mina's image of 
her naked body, but also by her photograph, which his mother "posted . . . on our refrigerator door .. . (American Dervish 2)." Hayat explains the ineffable effect the photo has on him both physically and psychologically. "One night I lost myself. Mina's picture before me, my hands between my legs, I disappeared into pleasure. Before I knew it, my loins shuddered and convulsed, releasing something thick and wet inside my underwear (American Dervish 162)."

In addition to Mina's image of the naked body and photo, Mina's physical proximity to Hayat disturbs him and ineffably quakes his body. "Mina leaned in to turn the page. Her arm brushed against mine, her touch whispering along my skin and echoing up my arm to the back of my neck (American Dervish 37)."

On another occasion, Mina takes the young boy into her arms, reminding him that he would become a hafiz someday. It is a moment which witnesses the amalgam of both physical and intellectual motives. Mina intends to remind him of becoming a hafiz while he is entirely obsessed with her exquisite beauty and convulsed with strong emotions. "She took me into her arms, and all at once I felt it again: that exquisite shudder running along my limbs, up my back (American Dervish 42)."

Third, from the very outset of the novel, it seems quite obvious that Hayat is far closer to his mother than to his father. Hence, the reader expects Hayat to follow his mother's steps in revering her views regarding the Jews. This is the reason why Ayad Akhtar starts his novel with Hayat and Rachel's intimate relation in the prologue and ends the novel with the same relation in the epilogue. Beginning and ending the novel with the intimacy of the relationship between Hayat and Rachel makes the core of the novel seem to be a midsummer night's dream. In other words, what comes between the prologue and the epilogue is just a narrative told by Hayat who speaks to Rachel about his 'auntie Mina'. Simply put, it is Rachel who asks Hayat to recount the story of his 'auntie Mina'. When he informs her of Mina's passing, she does not react as strongly as he expects her to, but she finally does. Hayat stands frozen in an attempt to hear a word uttered by Rachel to ask him to recount Mina's story.

I didn't move. The fact was, I didn't want to leave. I wanted to stay. I wanted to tell her.

We sat in silence for a long moment, and then Rachel reached out to touch my hand.

"Tell me," she said (American Dervish 132)."

Had Rachel not asked Hayat to tell Mina's story, there would have been no American Dervish at all. Hence, one can safely say that the whole story is narrated at Rachel's own request.

Henceforth, a young boy like Hayat who is tutored by the beautiful Mina can be neither a dervish nor a hafiz. It is perhaps part of the author's craftsmanship to show Hayat's abortive attempt to be either a dervish or a hafiz when Akhtar portrays Hayat's life as being possessed by his infatuation with his mentor, Mina.

\section{Hayat's Father and the Loss of Identity}

\subsection{Naveed Shah and His Family}

The other character who represents the loss of Islamic identity among the elder generation in American Dervish is Hayat's father-Naveed Shah. Throughout the novel, the author makes it quite apparent that Naveed is a detestable character for a handful of reasons.

First, his wife Muneer mentions nothing about him but his relations with the white mistresses. Hayat, the son, observes, "I heard more tales from Mother about Father's mistresses than anything else (American Dervish 33)." The son also remembers his father's problems with his family. Regarding this point, Hayat says: "Throughout my childhood, Mother spared me little detail about her troubles with Father. And at ten, I already knew myself well enough to know that if I listened too closely to what she said, my blood would start to boil (American Dervish 11)."

Second, he is contrasted with his colleague Professor Nathan Wolfsohn who is "from Boston, Jewish, urbane, and pleasantly gregarious (American Dervish 68)." Naveed, on the other hand, is from "a third-world village, Muslim, rough-hewn, and sardonic. Their colleagues at the hospital called them the Odd Couple (American Dervish 68)." To make their contrast more ostensible, Naveed's son adds that "the butt of most of Father's jokes was Nathan's love for all things cultural: the theater, symphonies, art museums, and above all books (American Dervish 68)." Simply put, Naveed's detestable characteristics become quite apparent when he is culturally compared to Nathan Wolfsohn.

Third, his family ties are broken and his relations with both wife and son fall asunder. Hayat refers to his parents' severed relations when he states, "My parents now fought as they never had. They cursed and slammed doors and threatened to leave each other. More than once, Father walked out, car keys in hand, and didn't come back until the next day. Or even later (American Dervish 241)."

Fourth, he maltreats his wife. Muneer the wife regards, "All I wanted was to know how he was feeling! That's all! And if he didn't want to say anything, he should just tell me. But no! Instead he finds a way to hurt me. He's a cruel man (American Dervish 144)." Hayat the son also affirms that his mother's marriage to his father has been a miserable one from its very start. "My parents' marriage was difficult almost from the start. . . . In short, by the time I was ten, she'd been miserable for years (American Dervish 9)."

Fifth, Naveed tells his wife Muneer that he hates her as much as he adores the white women. Muneer adds "He doesn't like my mouth, he told me. Not the way he likes the mouths of his white prostitutes. Free hearts, free minds, free mouths, he said. Not like Eastern women, who are heavy and dark and mentally imprisoned (American Dervish 144)." Naveed, as a husband, has no respect in his wife's eyes. She points out, "After all, a man who drank and cheated on his wife couldn't claim to have any credibility, she liked to say 
(American Dervish 167)." All these bad traits of Naveed's character can be regarded as part of his loss of Islamic identity.

\subsection{Naveed's Abhorrence of Religion in General and the Quran in Particular}

Such a loss of identity is also exposed in his abhorrence of the act of praying five times a day. To Naveed, doing this is nothing but a kind of hypocrisy. He says, "Praying all day long. Nothing to show for it. They're hypocrites (American Dervish 72)."

Again, it is Naveed who has gravely affected his wife in such a way that she begins to be dubious about her religious beliefs. This stresses his terrible impact upon those around him, particularly the members of his family. Hayat sheds light on this point when he says, "Deep down, Mother was a believer, but the years she'd spent with Father-who thought religion was for fools - had trained her, I think, to check her religious impulses (American Dervish 33)." To Naveed, religion would do no good to people; hence, they should abjure it. He says, "Religion, my friends . . . is a topic for fools. And this conversation is the living proof (American Dervish 130)." Consequently, he believes that going to a mosque to pray is a kind of idiocy, and it is the idiots who go to masjid: "There are idiots enough here for someone to lead. . . . Chatha and all those stooges with their masjid on the South Side. Be grateful you don't know any of them yet (American Dervish 48)." No wonder, then, that Naveed scorns all aspects of religion, as stressed by Randy Boyagoda when she says: "Hayat's father is a philandering alcoholic neurologist who wears his atheism proudly, scorns the local immigrant Muslim community, and regards all religions and Islam in particular as backward and embarrassingly crude."

Likewise, Naveed prevents Mina from teaching the tenets of Islam to his son, and the Quran, in particular. Mina says: "Your father asked me not to participate in your religious study anymore. He made me promise and ... I have to honor his promise. I am his guest, after all (American Dervish 240)." Part of Mina's assimilation into society lies in her succumbing to her guest's rules and in keeping her promises not to teach Hayat the Islamic lessons.

Naveed does not find his pleasure at home; quite the contrary, he finds it in his joyful stay with the white mistresses. His wife confirms this point when she says, "What has your Father sacrificed for my sake? Hmm? Tell me! Not even one night's pleasure with one of his white prostitutes... (American Dervish 141)."

Most importantly, he desecrates the Quran since it means nothing to him. It is also quite apparent that the Quran is the foundation of his displeasure as it symbolizes his homeland, fellow people, religion, and most notably Islam. The way Naveed treats the Quran evidently shows his deep resentment of this religion.

He pulled and tore, pages and pieces of pages falling to his feet. He tore and tore and before long the carpet was covered with paper. And now Father danced and ground the pages underfoot. He had a wild look in his eye as he stepped madly on the pieces of our holy book (American Dervish 231).

Naveed's reason for tearing the Quran into pieces and desecrating its tenets lies in his animosity of the wicked Muslim people as he sees them. To him, it is an indirect way of warning his son of such 'stooges' as he calls them. Naveed declares that there is no man of God who can love God as much as he can love money. Yet, his lifelong friend, Nathan the Jewish professor, refutes his statement saying that his "dad had a close friend who was a rabbi. He was a good man. Genuinely. A really good man. People in his synagogue adored him (American Dervish 166)." But since Naveed does not believe in the sanctity of any Muslim around him, he curses everything that is related to Islam and particularly the Quran. He speaks to his son this way:

That's the truth. I know you don't understand why I burned your Quran, but there was a reason. It's because you're different. You can't live life by rules others give you. In that way, you and I are the same. You have to find your own rules. All my life I've been running away from their rules, Hayat. All my life. You will be the same. Don't ask me how I know it, but I do (American Dervish 304).

\section{The Author and Islam}

As shown in American Dervish, the foremost theme in the novel seems to be the loss of the Muslim American identity in America at the time when the novel was penned. Such a theme focuses the reader's attention on the issue of adhering to the Islamic belief in America in the Post 9/11 Era. It is a message from the author to show to what extent it is so difficult to adhere to one's belief once they find themselves assimilating with other people of different beliefs and suffering because of their own creeds.

In his conversation with Anita Montgomery, Ayad Akhtar points out that immigrants usually struggle with what views to live with and what views to discard. In this concern, he says, "I think every immigrant community, whether they're defined by their faith or by their national identity, goes through this process of wrestling with what to hold on to and what to leave behind." In such a wrestling process, the Muslim-Pakistani-American immigrants are expected to thrust aside their Islamic beliefs. In his reference to his Pulitzer-winning play Disgraced (2012), Akhtar observes: "I wanted to write a tragedy, which required a reversal of Amir's fortunes due to some human flaw. In Amir's case it would be denial. Denial of his Muslim heritage, which a post 9/11 America will not let him forget (How Hamlet Inspired Playwright Ayad Akhtar to Create a Magnetic Role for Aasif Mandvi in Disgraced.)" Likewise in American Dervish, Ayad Akhtar focuses on the Pakistani immigrants, mainly represented in the novel by both Naveed, the father, and Hayat, the son. It is Hayat who experiences the woes and throes of an immigrant in an attempt to find his identity. "The child of immigrants struggles to find a place in his life for the traditions and beliefs of his ancestral homeland in a new world of broader possibilities that are both enticing and threatening (Wendy Smith.)" Again, the novel tackles the 
way how Muslims encounter problems in a new community. Roddy Ashworth points out that " In Akhtar's skillful hands, American dervish helps non-Muslims understand the difficulties of following deeply held religious beliefs in a secular society, although we see hayat [sic] lose his Muslim faith."

To live among other people of different cultures, one has to adapt himself in some way to accept the other. Isabel Fernandes points out that "The recognition that we are human beings lost in the middle of a living cosmos determines that each moment of our lives we are compelled to establish a changing relation to our circumambient universe."

\section{Conclusion}

Though American Dervish is Ayad Akhtar's debut novel, it is "a sensitive coming-of-age story (David Daley in USA Today)." The novel astutely depicts social, cultural and religious clashes since it "bridge[s] cultural divides and build[s] understanding, and Akhtar tells a rich and heartbreaking story about the limits of religion and the hazards of love (David Daley in USA Today)." It is no wonder that American Dervish crystallizes the heated struggle between generations, religions, cultures and races. "Mr. Akhtar's astute observations of the clashes between old world and new, between secular and sacred, among immigrants might seem familiar to readers of both contemporary and classic literature (Adam Langer)."

Again, the promising playwright and novelist Ayad Akhtar has skillfully written one of the well-wrought American novels. His works usually tackle the problems encountered by the Muslim immigrants who live in western communities, in general, and America, in particular. He thinks of himself as "a narrative artist. I don't think of myself as a novelist or screenwriter or playwright. All of those modalities . . . are obviously very different, and I'm not sure that I prefer any one to the other (Aditi Sriram interviews Ayad Akhtar)." Thematically, the author skillfully succeeds in conveying his message that it seems to be more than impossible to keep hold of one's beliefs in America, particularly if they are Muslims. Readers can plainly see this in most of his works, and particularly in American Dervish and Disgraced. Also from the structural standpoint, the author aptly makes great strides in manipulating the technique of flashbacks to show to what extent the protagonist of the novel recounts all the novel's events just to quench Rachel's thirst for listening to Mina's story, narrated by Hayat. Had she not been interested in listening to Mina's story, there would have been no American Dervish. It is also noteworthy to show to what extent Akhtar has been ineffably affected by a good number of western theologians. In his interview with Aditi Sriram, Ayad Akhtar mentions many of the theologians who have their great impact on him such as Jonathan Edwards, Emerson, Reinhold Niebuhr, Paul Tillich and some great authors such as Saul Bellow, Philip Roth, Woody Allen, Seinfeld (Aditi Sriram interviews Ayad Akhtar). Being profoundly affected by western writers, thinkers, and theologians makes it quite apparent that Akhtar, in his works, tackles a handful of themes in which he shows the clashes between east and west in addition to other issues such as religion, Islam vs. Judaism, Islamophobia, terrorism, ethnicity, and cultural clashes.

\section{References}

[1] Aditi Sriram interviews Ayad Akhtar. Guernica: A Magazine of Art and Politics. Notes for the Stage. June 2, 2014.

[2] Akhtar, Ayad (2012-01-09). American Dervish: A Novel. Little, Brown and Company. New York. Kindle Edition.

[3] Akhtar, Ayad. Bio. http://ayadakhtar.com/ American Dervish. Wikipedia, the free encyclopedia. 20 June 2015. https://en.wikipedia.org/wiki/American_Dervish.

[4] Ashworth, Roddy. "Review: American Dervish by Ayad Akhtar." Express. Sun, Jan 29, 2012. http://www.express.co.uk/entertainment/books/298728/Revie w-American-Dervish-by-Ayad-Akhtar.

[5] Berner, Heike. Home Is Where the Heart Is? Identity and Belonging in Asian American Literature. Doktor der Philosophie. Fakultät für Philologie. Ruhr-Universität Bochum. 2003.

[6] Boyagoda. Randy. "Teenage Muslim Misadventures." First Things. A Review of American Dervish. Nove mb er 2012. http://www.firstthings.com/article/2012/11/teenage-muslimmisadventures.

[7] Elizabeth Marie Crosby. Exploring Stigma, Identity Gaps, and Consumption. Doctor of Philosophy in Business Administration. The Graduate College of the University of Illinois at Urbana-Champaign. Urbana, Illinois, 2012.

[8] Daley, David. "Plot contrivances whirl in 'American Dervish'." USA TODAY. USA TODAY R Review. February 05, 2012. http://books.usatoday.com/book/ayad-akhtaramerican-dervish/r619957.

[9] Fernandes, Isabel. "To be, or not to be, is still the question": Identity and "Otherness" in D. H. Lawrence's Work. http://ler.letras.up.pt/uploads/ficheiros/4226.pdf.

[10] Hooti, Noorbakhsh. "The Quest for Identity in Arthur Miller's 'The crucible."' English Department, Faculty of Arts, Razi University, Kermanshah, Iran. Journal of English and Literature Vol. 2(3), pp. 68-74, March 2011. Full Length Research Paper. http://www.academicjournals.org/ijel.

[11] How Hamlet Inspired Playwright Ayad Akhtar to Create a Magnetic Role for Aasif Mandvi in Disgraced by Ayad Akhtar. Broadway Buzz. October 23, 2012.http://www.broadway.com/buzz/164963/how-hamletinspired-playwright-ayad-akhtar-to-create-a-magnetic-rolefor-aasif-mandvi-in-disgraced/.

[12] Huang, Shih-Yi. The Dialogism of Self and Other in Contemporary American Drama. Diss. Louisiana State University. Louisiana. 2010.

[13] Interview with Ayad Akhtar, AN. ACT: A Contemporary Theatre. "A Conversation Between Playwright Ayad Akhtar and Anita Montgomery" http://www.acttheatre.org/Downloads/AyadAkhtarInterview.pdf. 
[14] Langer, Adam. "Stumbling Through an American Muslim Maze." The New York Times. January 4, 2012. http://www.nytimes.com/2012/01/05/books/american-dervishby-ayad-akhtar-review.html?_r=0.

[15] Moody, Lisa Irene. Religion and Realism in Late Nineteenthcentury American Literature. Diss. Louisiana State University. Louisiana. 2009.

[16] Sillman, Marcie. Playwright Ayad Akhtar in Search of the Modern Muslim. Sep 11, 2014 http://kuow.org/post/playwright-ayad-akhtar-search-modernmuslim.

[17] Smith, Wendy. 'American Dervish' is a fine contemporary coming-of-age story. The Washington Post. January 19, 2012 $\mathrm{http}: / / \mathrm{www}$.washingtonpost.com/entertainment/books/america n-dervish-is-a-fine-contemporary-coming-of-agestory/2012/01/06/gIQAWqnvBQ_story.html.

[18] Tsang Sze Pui, Jappe. The Search for Identity in Things fall Apart, A Man of the People, Anthills of the Savannah and Selected Essays by Chinua Achebe. Master of Arts. The University of Hong Kong. August 2001.

[19] Writing About the Midwestern Muslim Experience. Jan., 17, 2012. $\mathrm{npr}$ books http://www.npr.org/2012/01/17/145334491/writing-about-themidwestern-muslim-experience. 